PART SIX

THE THIRD GENTURY AD 


\title{
THE MILITARY FACTOR IN THE ONSET OF GRISES IN THE ROMAN EMPIRE IN THE THIRD GENTURY AD
}

\author{
LUKAS DE BLOIS
}

In this paper I would like to discuss the impact of Roman armed forces on the rise of crises in the Roman Empire in the third century AD. ${ }^{1}$ In my view the first half of this century - and more specifically the two decades from 230 to about 250 - may be characterized as a period of increasing regional troubles that ripened into a series of crises, which beset the Roman Empire in the period 251 to 284. There were great regional differences. Dacia, some neighbouring Danube lands, and the Agri Decumates, for example, had a bad time, but other territories were still relatively prosperous, in spite of fiscal pressures. In 1999 Witschel demonstrated that until the third quarter of the third century regions like Italy, Gaul, Britain, Spain, and Northern-Africa maintained their traditional infrastructures, their density of population and their prosperity. ${ }^{2}$

The traditional view is that the third century is an age of omnipresent warfare, which resulted in the rise of military power in the Roman Empire and in military demands that were an important cause of third century troubles, which affected the whole Empire. ${ }^{3}$ However,

\footnotetext{
${ }^{1}$ I owe thanks to Merton College, Oxford, where I prepared much of this paper during Hilary Term, 2004.

${ }^{2}$ Chr. Witschel, Krise-Rezession-Stagnation? Der Westen des Römischen Reiches im 3. Jahrhundert n. Chr. (Frankfurt a.M. 1999), 239-374. Cf. Chr. Witschel, 'Re-evaluating the Roman West in the 3rd c. AD', Fournal of Roman Archaeology 17 (2004), 251-281. On continuous prosperity in many parts of Asia Minor and the eastern provinces see F. Millar, The Roman Near East (Cambridge MA/London 1993), 225-436 passim, and S. Mitchell, Anatolia: Land, Men and Gods I (Oxford 2001, 2nd ed.), 227-240. Cf. H. Brandt, Gesellschaft und Wirtschaft Pamphyliens und Pisidiens im Altertum. Asia Minor Studien 7 (Bonn 1992), 100; 149f.

${ }^{3}$ On the third century crisis in the Roman empire see for example G. Alföldy, 'The Crisis of the Third Century as Seen by Contemporaries', Greek, Roman, and Byzantine Studies 15 (1974), 98-103 (= idem, Die Krise des römischen Reiches. Geschichte, Geschichtsschreibung und Geschichtsbetrachtung. Ausgewählte Beiträge (Stuttgart 1989), 328-333); M. Christol, L'empire romain du troisième siècle (Paris 1997); Witschel 1999, op. cit. (n. 2), passim; Witschel 2004, op. cit. (n. 2), 251-281; J.-M. Carrié \& A. Rousselle, L' empire romain en mutation des Sévères à Constantin, 192-337 (Paris 1999); L. de Blois, 'The Crisis of the Third Century AD in
} 
because many crises may have had a regional character, it might be wise to regionalize the 'third century crisis', more so than has been done so far.

In a discussion about the contribution of the military factor to the onset of crises in the Roman Empire in the third century AD attention should be paid, first of all, to military misconduct and rapacity, not only in zones of actual warfare, but also along frequently used military transit routes. Military unruliness is looming large in contemporary literary sources. In all his eighty books, which he probably wrote between $\mathrm{AD}$ 211 and 235, Cassius Dio is virtually obsessed with the risks of military power and misconduct. Herodian, in Dio's track, regarded the greed and lack of discipline of the soldiers as the root of much evil and in his opinion these vices were growing stronger. ${ }^{4}$ According to Alföldy

the Roman Empire: A Modern Myth?', in L. de Blois \& J. Rich, eds., The Transformation of Economic Life under the Roman Empire. Proceedings of the Second Workshop of the International Network Impact of Empire, Nottingham, Fuly 4-7, 2001 (Amsterdam 2002), 204-217; D.S. Potter, The Roman Empire at Bay AD 180-395 (London/New York 2004), 3-298; R.P. Duncan-Jones, 'Economic Change and the Transition to Late Antiquity', in S. Swain \& M. Edwards, eds., Approaching Late Antiquity. The Transition from Early to Late Empire (Oxford 2004), 20-52; P. Eich, Zur Metamorphose des politischen Systems in der römischen Kaiserzeit. Die Entstehung einer ,personalen Bürokratie im langen dritten Fahrhundert (Berlin 2005), and A.K. Bowman, P. Garnsey \& A. Cameron, eds., The Cambridge Ancient History XII: The Crisis of the Empire, $A D$ 193-337 (Cambridge 2005), esp. B. Campbell, 'The Severan Dynasty', 1-27; J. Drinkwater, 'Maximinus to Diocletian and the "crisis"', 28-66; B. Campbell, 'The Army', 110-120; E. Lo Cascio, 'The Emperor and his Administration', 131-169; J. Wilkes, 'Provinces and Frontiers', 212-268; J.-M. Carrié, 'Developments in Provincial and Local Administration', 269-312; M. Corbier, 'Coinage and Taxation: The State's Point of View, AD 193-337', 327-392; M. Corbier, 'Coinage, Society and Economy', 393-439.

${ }^{4}$ On Cassius Dio's life, career, political convictions, and views of the soldiery see F. Millar, A Study of Cassius Dio (Oxford 1964), 5-27; P.M.M. Leunissen, Konsuln und Konsulare in der Zeit von Commodus bis Severus Alexander (180-235 n.Chr.) (Amsterdam 1989), 163; M. Hose, Erneuerung der Vergangenheit. Die Historiker im Imperium Romanum von Florus bis Cassius Dio (Stuttgart 1994), 356ff.; L. de Blois, 'Volk und Soldaten bei Cassius Dio', in H. Temporini \& W. Haase, eds., Aufstieg und Niedergang der Römischen Welt II 34,3 (Berlin/New York 1997), 2650-2676; idem, Emperor and Empire in the Works of Greek-speaking Authors of the Third Century AD', in H. Temporini \& W. Haase, eds., Aufstieg und Niedergang der Römischen Welt II 34,4 (Berlin/New York 1998), 3405f. and 341 1f.; idem, 'The Perception of Emperor and Empire in Cassius Dio's Roman History, Ancient Society 29 (1998-1999), 275ff.; P.M. Swan, The Augustan Succession. An Historical Commentary on Cassius Dio's Roman History, Books 55-56 (9 BC-AD 14) (Oxford 2004), 3-17. On Herodian and his work see Alföldy 1989, op. cit. (n. 3), 240ff.; D. Roques, Hérodien, Histoire des empereurs romains de Marc Aurèle à Gordien III (180-238 ap. F.-C.) (Paris 1990), 1-15; H. Sidebottom, 'Herodian's Historical Methods and Understanding of History', in H. Temporini \& W. Haase, eds., Aufstieg und Niedergang der Römischen Welt II 34,4 (Berlin/New York 1998), 2775-2836; G. Marasco, ,Erodiano e la crisi dell'impero', ibid. 2837-2927; De Blois 1998, op. cit., ibid. 3415-3423; M. Zimmermann, 'Herodians 
and Polley, Herodian died after AD 250. So he may have seen more of third century troubles than Dio had. ${ }^{5}$

Outright loot and plunder could seriously damage regions where wars were raging or through which armies went from one war zone to another. From 230 and indeed from 249 dangerous wars arose in the East and North. Until 253 most wars did not yet coincide, but from 253 simultaneous fighting at several frontiers became a common feature of Roman history, which forced the emperors to move frequently vexillationes from the legions, auxiliary units and fleet detachments from one endangered region to another, to concentrate armies which would be big enough to beat the enemies. ${ }^{6}$ What about the consequences? There are no elaborate, detailed third century reports about such military movements, but in the Histories of Tacitus there is a story which may be used as an eye-opener. In Histories 1.63-69 Tacitus tells us how the Vitellian armies, led by Valens and Caecina, moved through Gaul and Switzerland to Italy. They took what they needed, humiliated local notables who gave the military what they needed in a very subservient way, and destroyed communities that seemed to put up some resistance. According to Tacitus at least one of the generals, Valens, became a very rich man through forced transactions with local proprietors. Tacitus' report is highly rhetorical, but it gives us a clue. Passing armies demanded goods, food, and facilities and could easily turn into looting mobs. So local magistrates gave them what they asked and could not resist. Local notables changed into subservient slaves of passing armies and must have lost face in the eyes of their fellow citizens, whom they were supposed to protect. There are just enough indications which suggest that similar things happened in the third century. Under Caracalla, Gordian III, and Philip the Arabian, already well before the intense military activity of the period 249-284, villagers from Takina, Skaptopare and Aragoe, places in the Balkans and Asia Minor, in the neighbourhood of military transit routes, complained to the emperors telling them that military avarice and misbehaviour had brought them into misery and

Konstruktion der Geschichte und sein Blick auf das stadtrömische Volk', in idem, ed., Geschichtsschreibung und politischer Wandel im 3. Fh. n.Chr. (Stuttgart 1999), 119-143; Th. Hidber, ,Zeit und Erzählperspektive in Herodians Geschichtswerk', in M. Zimmermann, ed., Geschichtsschreibung und politischer Wandel im 3. Fh. n.Chr. (Stuttgart 1999), 145-167.

${ }^{5}$ See Alföldy, Krise 1989, op. cit. (n. 3), 240ff.; A.R. Polley, 'The Date of Herodian's History', Antiquité Classique 72 (2003), 203-208.

${ }^{6}$ On the history of the tumultuous years 249-271 see Christol 1997, op. cit. (n. 3), 121-158. 
bankruptcy, which would ultimately lead to less tax returns from their regions. ${ }^{7}$ Like Valens, some commanders and officers may have fared very well. In 1992 Piet Sijpesteijn published a papyrus text about the descendants of a former third century centurion, the Aponii, who now belonged to the richest people of the Roman East. ${ }^{8}$

In zones of enduring or repeated actual warfare things could be worse, particularly when violence and devastation went hand-in-hand with forced recruitment of soldiers, deportation, banditry, famine and epidemics. A parallel text from the period of the emperor Marcus Aurelius, which gives a good indication about what must have happened in many regions in the third century, is P. Thmouis I from Northern Egypt, a region where, in the emperor Marcus' times, rebellion, violence and the Antonine plague caused widespread misery. ${ }^{9}$ In AD 167/8 the village was almost depopulated by a sequence of fatal events. Fellow villagers had gone away, in an act of anachoresis, to evade heavy taxation, which they could no longer bear, now that security was waning. Smaller numbers had to yield equally heavy taxes, which drove out more people. This resulted in a vicious circle. Besides, the village was ransacked by groups of rebellious boukoloi. The bandits were chased away by soldiers, who unfortunately killed most of the remaining villagers, whose ranks were further depleted by the plague. The few surviving villagers could no longer pay their dues, but tried to get back former fellow villagers in order to restore their carrying capacity. They were successful in finding them, but were chased away by landowners and farmers who had leased land to the runaways.

Another indication from the times of Marcus Aurelius is equally interesting. During his reign a bad situation arose in the Danube lands where the wars against Marcomans, Quadi, Iazyges and other tribes were mainly fought. Cassius Dio tells us that around AD 175, when a peace treaty was concluded with them, the Iazyges were still very

\footnotetext{
${ }^{7}$ See P. Herrmann, Hilferufe aus den römischen Provinzen. Ein Aspekt der Krise des römischen Reiches im 3. Fh. n.Chr. (Hamburg/Göttingen 1990) and T. Hauken, Petition and Response. An Epigraphic Study of Petitions to Roman Emperors 181-249. Monographs from the Norwegian Institute at Athens 2 (Bergen 1998), esp. 215f. (from Euhippe); idem 1998, op. cit., 217-243 (from Takina); Herrmann 1990, op. cit., nr. 4 = Hauken 1998, op. cit., 74-139 (= CIL suppl. 12336 = IGR I 674 = Sylloge 888, from Skaptopare); Herrmann 1990, op. cit., nr. 6 = Hauken 1998, op. cit., 140-161 (= OGIS 519 = IGR IV 598, from Aragoe). See F. Millar, The Emperor in the Roman World (London 1992, 2nd ed.), 646 (= SEG 37 (1987), 1186) and Eich 2005, op. cit. (n. 3), 121; 299-307.

${ }^{8}$ See P.J. Sijpesteijn, 'Aponii in Egypt', Zeitschrift fir Papyrologie und Epigraphik 90 (1992), 238f.

${ }^{9}$ See S. Kambitsis, Le papyrus Thmouis 1, colonnes 68-160 (Paris 1985), 25-31.
} 
strong. They had done, he continues, the Romans great harm, which was evident from the fact that the barbarians returned 100.000 captives that were still in their hands even after the many who had been sold, had died, or had escaped. To counter depopulation and an ensuing decrease of tax returns the emperor decided to settle Germanic tribesmen, for example some Naristi, in southern Germany, after in AD 180 a more definite peace treaty had been concluded with several warring tribes. ${ }^{10}$ The situation did not improve immediately, however, among other reasons because banditry was rampant. Under the emperor Commodus large bands, consisting of remaining barbarians, runaway soldiers and other drifters, were still very strong and could even besiege a Roman legion, the Octava Augusta, in its own camp. ${ }^{11}$

About AD 260 similar things must have happened again in the Danube regions. ${ }^{12}$ In 1.37.3 Zosimus tells us that around 260 the situation in 'Illyricum' was very bad indeed, because of barbarian invasions and the plague, which led to a depopulation of towns. Zosimus' story may be rhetorical and exaggerated, but the author must have found something in his sources. It is not very probable that his dark picture of the hinterlands of the Middle Danube limes in the third quarter of the third century is completely fictional.

The cost of military operations may also have afflicted the hinterlands of war zones, which had to produce extra supplies, although some of them, such as Syria, Asia Minor and the Po Valley, were doing rather well until beyond the middle of the century. Apparently heavy warfare in Mesopotamia and the Danube area did not destroy their prosperity. Obviously they had sufficient carrying capacity to produce the required surpluses and make a handsome profit as well, through trade with garrisons, merchants and non-combatants who followed the armies. ${ }^{13}$ Problems must have arisen earlier and quicker in thinly

10 See Cassius Dio 71.21.1.

11 See Herodian 1.10. See G. Alföldy, ,Bellum desertorum', in Alföldy 1989, op. cit. (n. 3), 69-80 (= Bonner Fahrbücher 171 (1971), 367-376) and O.J. Hekster, Commodus. An Emperor at the Crossroads (Amsterdam 2002), 45 n. 32; 65-67.

12 On the middle Danube area and Upper Moesia see A. Mócsy, Pannonia and Upper Moesia (London/Boston 1974), 203; 216f.; 263ff. On Noricum see G. Alföldy, Noricum (London/Boston 1974), 169ff. On a decline of settlements in the Agri Decumates and in Raetia, which manifests itself in archaeological traces and findings, see Witschel 1999, op. cit. (n. 2), 207ff. Cf. Wilkes 2005, op. cit. (n. 3), 212-230 passim.

13 See publications by F. Millar, Chr. Witschel and S. Mitchell mentioned above in note 2. See Elio Lo Cascio's contribution to this volume. He argues that extra requisitions caused problems, but that trade with fixed garrisons and - I would like to add - canabae must have been profitable to the hinterlands of frontier zones. 
populated regions without reserve capacities, where military demands repeatedly took away whole year-surpluses and more, and where forced recruitment, anachoresis and banditry brought about a relatively serious decrease in people who paid taxes and furnished supplies.

In times in which emperors became completely dependent on the armies for their own survival they could not economize on their military budget. They simply had to meet military necessities and demands. An important effect of heavy military expenditure may have been the debasement of the coinage. Changes in army pay and other military expenditure immediately affected the imperial budget, because - if Duncan-Jones is right - the armed forces took about three quarters of the imperial income. ${ }^{14}$ A debasement of the imperial coinage set in under Commodus, who had to adjust the coinage to the rise in prices and wages that had come about between 160 and 190, as a result of the Antonine plague, and under Septimius Severus (193-211), who had raised the pay of the soldiers by $50 \%$. In my view he did so in order to attract good recruits in sufficient numbers in times of shrunken populations and higher prices and wages, caused by the Antonine plague, which in Egypt, for example, may have taken away $20 \%$ or more of the population. ${ }^{15}$ The debasement of the coinage may have been caused by a rising military budget, decreasing tax returns and-particularly from 253 - the decentralisation and enlargement of imperial coin production. ${ }^{16}$ A lack of plate may also have contributed to the

14 See R.P. Duncan-Jones, Money and Government in the Roman Empire (Cambridge 1994), 47ff.

${ }^{15}$ On the consequences of the Antonine plague see R.J. Littman \& M.L. Littman, 'Galen and the Antonine Plague', American fournal of Philology 94 (1973), 243-255; D.W. Rathbone, 'Villages, Land and Population in Graeco-Roman Egypt, Proceedings of the Cambridge Philological Society n.s. 36, 216 (1990), 119; R.P. Duncan-Jones, 'The Impact of the Antonine Plague', fournal of Roman Archaeology 9 (1996), 108-136; R.S. Bagnall, 'P.Oxy. 4527 and the Antonine Plague in Egypt. Death or Flight?', Fournal of Roman Archaeology 13 (2000), 288-292; idem, 'The Effects of the Plague: Model and Evidence', fournal of Roman Archaeology 15 (2002), 114-120; W. Scheidel, 'A Model of Demographic and Economic Change in Roman Egypt after the Antonine Plague', fournal of Roman Archaeology 15 (2002), 97-114; Chr. Bruun, 'The Antonine Plague in Rome and Ostia', Journal of Roman Archaeology 16 (2003), 426-434.

${ }^{16}$ On the debasement of the coinage in the third century AD see R.A.G. Carson, Coins of the Roman Empire (London/New York 1990), 61ff.; R.F. Bland, 'The Development of Gold and Silver Coin Denominations, AD 193-253', in C.E. King \& D.G. Wigg, Coin Finds and Coin Use in the Roman World. The Thirteenth Oxford Symposium on Coinage and Monetary History, 25.-27.3.1993 (Berlin 1996), 63-100; K.W. Harl, Coinage in the Roman Economy, $300 B C$ to $A D 700$ (Baltimore/London 1996), 126-148; J.-M. Carrié \& A. Rousselle, L'empire romain en mutation. Des Sévères à Constantin, 192-337 (Paris 1999), 127ff.; Corbier 2005, op. cit. (n. 3), 330-392. 
debasement of the imperial coinage. ${ }^{17}$ After the reign of Septimius Severus his son Caracalla introduced a new silver coin denomination, the antoninianus, which had a nominal value of two denarii, but contained the silver of about 1,5 denarii. Severus Alexander and Maximinus Thrax did no longer produce such antoniniani and tried to maintain the silver content and weight of their denarii - if we may believe the graphs of Bland $^{18}$-, but from 238 the emperors had to give in to pressing needs and reverted to Caracalla's debased antoniniani. From the reign of Philippus Arabs Roman imperial silver coinage was progressively debased, until it reached a silver content of less than $2 \%$ under Claudius II, about 269. So far this did not yet result in a universal empire-wide rise in prices, if we may believe Hans Drexhage, Elio Lo Cascio and Dominic Rathbone. Silver coins had become token money. Prices only skyrocketed after the emperor Aurelian had given up the fixed relation between silver and gold coins, in this way undermining popular trust in the imperial silver coinage. ${ }^{19}$

So, were Cassius Dio and Herodian right and were the soldiers the prime cause of misery? Or was the military factor in the onset of crises a function of other factors and not the main cause of the problems? First of all, actual continuous warfare at various borders created military demands, losses and a rise of military expenditure, and so increasing military expenditure was a function of intensified warfare. However, there are other factors too: the effects of recurrent waves of plague and ensuing rises in prices and wages, the weakening of imperial authority, and the unwilling attitude of parts of the population to give the central

17 See Chr. Howgego, 'The Supply and Use of Money in the Roman World, 200 BC-AD 300', Fournal of Roman Studies 82 (1992), 1-31. In Corbier's view the emperors' financial needs were the main reason, not a lack of precious metals; see Corbier 2005, op. cit. (n. 3), 390. Cf. Lo Cascio 2005, op. cit. (n. 3), 154 f.

${ }_{18}^{18}$ Bland 1996, op. cit. (n. 16).

${ }_{19}$ See H.-J. Drexhage, Preise, Mieten/Pachten, Kosten und Löhne im römischen Aegypten bis zum Regierungsantritt Diokletians (St. Katharinen 1991); E. Lo Cascio, 'Dall' antoninianus al ,laureato grande': l'evoluzione monetaria del III secolo alla luce della nuova documentazione di età diocleziana', Opus 3 (1984), 135-201; idem, ,Dinamiche economiche e politiche fiscali fra I Severi ed Aureliano', in Storia di Roma Einaudi III 1 (Turin 1993), 276ff;; idem, 'How did the Romans view their Coinage and its Function?', in C.E. King \& D.G. Wigg, Coin Finds and Coin Use in the Roman World. The Thirteenth Oxford Symposium on Coinage and Monetary History, 25--27.3.1993 (Berlin 1996), 281; D.W. Rathbone, 'Monetisation, not Price-inflation, in Third Century AD Egypt?', in C.E. King \& D.G. Wigg, eds., Coin Finds and Coin Use in the Roman World (Berlin 1996), 321-339; idem, 'Prices and Price-Formation in Roman Egypt', in J. Andreau et al., eds., Economie antique: prix et formation des prix dans les economies antiques (Saint Bertrand de Comminges 1997), 183-244. 
administration what it needed. There is no certainty about the demographical damage caused by the second plague, which may have hit regions of the Roman Empire in varying intensity and in several waves during two or three decades beyond AD 250. Cyprian is referring to it in his Ad Demetrianum, Eusebius is speaking about it in his Ecclesiastical History, book 7, and Zosimus ascribes in 1.37 .3 a depopulation of towns in Illyricum, as he calls it, partly to the plague. ${ }^{20}$ In relatively thinly populated regions where forced recruitment, deportations and actual warfare had already diminished the number of farmers and other productive people, such as the hinterlands of the Danube border and the Agri Decumates, the effects may have been serious, and the balance between productive and non-productive military people, who were dependent on surpluses created by others, may have become precarious. A period of plague made labour scarcer and so gave labourers and farmers a better bargaining position. If they ran away from their villages, by anachoresis, they could heavily diminish tax-returns of their region. Even before the second plague, under Philip the Arabian, farmers living on an imperial estate at the village of Aragoe, like other villagers in other third century petitions, overtly suggested that returns might go down if the emperor would not listen to them. ${ }^{21}$ If such things happened, military units at neighbouring borders, which were largely dependent on surpluses generated by their hinterland, may have come into trouble and may have become prone to rebellion and usurpation, particularly if invaders had destroyed their properties in the limes-region, which they were allowed to own from the days of Septimius Severus. Another result must have been that hinterlands which were lying further away, at a greater distance from the border, were to bear more taxation and requisition of supplies. For example in Egypt, where under Philip the Arabian, after heavy warfare at the eastern borders, a kind of reorganization became a necessity, probably to enlarge its export of military supplies, especially food. Many years ago Peter Parsons convincingly

20 See Cyprian, Ad Demetrianum 3-10; idem, De mortalitate 2 (cf. Alföldy 1989, op. cit. (n. 3), 309). See Eusebius, Historia ecclesiastica 7.21-22; Zosimus 1.37.3. Cf. E. Lo Cascio, ,La dissoluzione dell'impero Romano d'Occidente: la spiegazione demografica', in G. Cacciatore, et al., eds., Filosofia e storia della cultura. Studi in onore di Fulvio Tessitore (Naples 1997), 168ff. and Carrié \& Rousselle 1999, op. cit. (n. 3), 521ff.

${ }_{21}$ See Hauken 1998, op. cit. (n. 7), 35ff., esp. 41, on a text from Aga Bey Köyü (Lydia) dating from 197-211 or 244-249, and 149, on a petition from Aragoe in Phrygia. See above, note 7. Cf. Hauken 1998, op. cit. (n. 7), 173 on a text from Dagis in Moesia Inferior, from 159-160, a parallel text. 
argued that the administration of Egypt was reorganized under this emperor. In the second edition of Cambridge Ancient History XII Alan Bowman argues that under Philip the Arabian a coherent reform was carried into effect, which mainly focused on landholdings and liturgies and implied an overhaul of the taxation system and the annona militaris. ${ }^{22}$ Another example: Northern Italy. A passage in Herodian's work is very interesting in this respect. In 8.2.3 he tells us that many goods found their way to the Danubian provinces through Aquileia. Is he speaking about trade and nothing else? That is not likely. Apart from the armies there cannot have been many communities in that region, which attracted large amounts of imported goods. Besides, Herodian is speaking about the year AD 238, which was preceded by the wars that Maximinus Thrax conducted against tribes in Germany, over the Alps. ${ }^{23}$ These wars must have been serious. If there is any historicity in Herodian's highly rhetorical report, in 7.3, Maximinus had to grab all kinds of reserve money to finance them, even from temples, sanctuaries of the imperial cult included, as Ittai Gradel convincingly argued in a recently published book. ${ }^{24}$ In those days Maximinus was not very popular in Italy, as events of the year 238 clearly showed. But again, Northern Italy did not enter a period of decay or crisis in those years; obviously it had sufficient carrying capacity. ${ }^{25}$

${ }^{22}$ During the later 240 s the emperor Philip had to take rather strong measures to maintain Egyptian contributions at their traditional level. According to Peter Parsons, low Niles and defective inundations are to be blamed. But in my view we should add stronger state demands and more state purchases, followed by anachoresis, preferably to large well-protected domains. See P.J. Parsons, Fournal of Roman Studies 57 (1967), $134 \mathrm{ff}$ and idem, P.Oxy. 42, pp. $110 \mathrm{ff}$, nrs. 3046-3050. See A.K. Bowman, 'Egypt from Septimius Severus to the Death of Constantine, op. cit. (n. 3), $318 f$.

${ }_{23}$ Herodian 7.2. On the fateful year AD 238 and the preceding reign of Maximinus Thrax see now K. Haegemans, Imperial Authority and Dissent. The Roman Empire in $A D$ 235-238 (diss. Leuven 2005). A commercial edition will be published by Peeters, Leuven, probably in 2007.

${ }^{24}$ Herodian 7.3.5-6: "After Maximinus had reduced most of the distinguished families to penury, he then began to think it was an unimportant, insignificant activity and not enough to satisfy his desire. So he turned to expropriate any money in the city being collected for food supply and cash distribution to the common people, and funds put aside for theatres and festivals. Temple dedications, statues of the gods, honorary presentations to the heroes (or: 'deified emperors'?), any ornamentation on public buildings or city decorations, or material that could be turned into coin was all melted down." See I. Gradel, Emperor Worship and Roman Religion (Oxford 2002), 356ff.

${ }^{25}$ On Northern Italy see Witschel 1999, op. cit. (n. 2), 255-258: only in the later third century there were signs of depression in Northern Italy, after which a phase of recovery followed in the fourth century. Cf. Witschel 2004, op. cit. (n. 2), 265. 
Another factor certainly contributed to third century military unruliness, i.e. the erosion of imperial authority, which precluded strict attitudes towards the military. After the times of Caracalla, dynastic succession became problematic and child-emperors could not rely on a record of res gestae. The religiously tinged ideological compensation that Commodus and Elagabalus had sought in emphasizing protection by a favourite all-powerful deity could no longer work after the demise of Elagabalus. Severus Alexander had to return to a rather conservative religious policy. ${ }^{26}$ There are visible signs of a decline of imperial authority. Under Hadrian one could still speak to rapacious military people in a rather harsh tone. In a papyrus text, PSI 446, we read:

I (i.e. the praefectus Aegypti $[L d B])$ am informed that without having a warrant many of the soldiers when travelling through the country requisition boats and animals and persons improperly, in some cases seizing them by force, in other obtaining them from the strategi through favour or obsequiousness, the result of which is that private persons are subjected to insults and abuses and the army is reproached for greed and injustice. The prefect commands never to furnish to any person without a warrant any contribution for the journey. ${ }^{27}$

In the third century, emperors rather advised people who petitioned them for help to turn to their governor. ${ }^{28}$ Already under Severus Alexander groups of soldiers turned against non-military men who tried to rule them in an old-fashioned disciplinary way, by real severitas. Cassius Dio, who had behaved in this way in Pannonia, became one of their victims. Messages went to the praetorians in Rome, who saw to it that the emperor Severus Alexander sent Dio away, outside Rome, during the period of his second consulship, which he was to hold together with the emperor himself. This was a mortal blow to Dio's prestige. ${ }^{29}$

${ }^{26}$ See Hekster 2002, op. cit. (n. 11), 87-136; L. de Blois, 'Emperorship in a Period of Crisis: Changes in Emperor Worship, Imperial Ideology and Perceptions of Imperial Authority in the Roman Empire in the Third Century $A D$ ' and M. Icks, 'Priesthood and Imperial Power. The Religious Reforms of Heliogabalus, 220-222 AD', both in P. Funke, J. Hahn \& L. de Blois, eds., The Impact of Imperial Rome on Religions, Ritual and Religious Life in the Roman Empire. Proceedings of the Fifth Workshop of the International Network Impact of Empire (Roman Empire, 200 BC-AD 476), Münster, Fune 30-Fuly 3, 2004 (Leiden/Boston 2006).

${ }_{27}$ PSI $446=$ A.S. Hunt \& C.C. Edgar, Select Papyri II (London/Cambridge, Mass. 1956), nr. 221.

${ }^{28}$ See for example Sylloge ${ }^{3}$ II 888, 1l.108-122 (from Skaptopare, see above note 7); OGIS II 519, 1l. 26f. (from Aragoe, see above, note 7).

${ }^{29}$ See Cassius Dio 80.4-5. 
In conclusion: the military factor was quintessential in the rise of problems and crises in the Roman Empire in the third century, but it was itself a function of coinciding developments: the intensification of actual warfare, ensuing devastations, epidemics and deportations, a change in the bargaining position of surviving productive people in war areas, who could take refuge in anachoresis, and a deterioration of actual imperial authority, which became visible in imperial rescripts about military misconduct and the decreasing power of cultured, unmilitary high status aristocrats, who co-operated with emperors who wanted to continue Antonine traditions. 